\title{
Assessment of Fishery Resources in the Lagonoy Gulf, Philippines
}

\author{
Virginia L. Olaño ${ }^{1}$, Noemi SB. Lanzuela ${ }^{1, \star}$, Kristine SM. Paredes $^{1}$ \\ National Stock Assessment Program \\ Bureau of Fisheries and Aquatic Resources Region V
}

\section{A B S T R A C T}

The Lagonoy Gulf is one of the largest and most important fishing grounds in the Bicol Region. It is endowed with commercially important finfish and is characterized by a multi-species and a multi-gear fishery. Assessment of marine fishery resources was done to determine the status of the gulf and to evaluate the effects of fishing activities in support to fisheries management. The data used were from 1998 to 2012. Consolidated results from the National Stock Assessment Program (NSAP) of Region V were collected along the determined landing sites in the provinces of Albay and Camarines Sur. The results showed that catch composition was dominated by small pelagics (43.83\%), followed by large pelagics (42.18\%), and demersal fishes (13.94\%). It is also noted that $89-98 \%$ of the small pelagic species were caught below the length at first maturity and their vulnerability to several fishing gears resulted in growth overfishing. Analysis of the growth parameters indicated that the species were relatively fast-growing and short-lived - $\mathrm{L}_{\infty}$ ranges from 24.92 for Indian scad (Decapterus russelli) to 52.81 for Frigate tuna (Auxis thazard); and a k value of 0.85 for the same species (A. thazard) to 1.34 for Indian mackerel (Rastrelliger kanagurta). The total mortality rate is high, ranging from 7.02, as manifested in Bigeye scad (Selar crumenophthalmus), to 13.13 for the Island mackerel (R. faughni). Lagonoy Gulf also suffers from overexploitation, in which computed $E$ values were far beyond the optimum level of exploitation ( $E$ ranges from 0.69 to 0.84 ), which is the result of heavy fishing pressure in the area.

‘E-mail: noemilanzuela@gmail.com

Received: 9 June 2017

Accepted: 22 October 2017
Keywords: catch composition, length-at-first maturity, $k$-value, exploitation value, total mortality, Lagonoy Gulf, assessment, fishery resources

\section{I N T R O D U C T I O N}

I n 1998, the National Stock Assessment Program (NSAP) of Bureau of Fisheries and Aquatic Resources Region V started to conduct an in-depth assessment of fisheries resources in Lagonoy Gulf, one of the major fishing grounds in the Bicol Region.

The said gulf is one of the region's and country's most productive fishing grounds. It is an important fishing ground for elasmobranchs such as sharks and rays. This gulf is endowed with commercially important finfish such as tuna, tuna-like species, and billfish.

The municipal fishers of this gulf use a variety of fishing gears like, but not limited to, handlines and gillnets, while the commercial fishers are commonly engaging in ring net and bag net operations.

The coastal ecosystem along Lagonoy Gulf is also suffering from degradation of its corals, mangroves, and seagrasses. Feedback from the fisherfolk community confirms that their catch has been declining due to the massive destruction caused by fishing activities (BFAR V FARMC-PMC report 2012).

Poverty and food security are among the major concerns that cannot be ignored in the coastal areas where most of the inhabitants rely on fishing for livelihood. About 9,939 individuals residing along the coastline bordering the gulf is directly dependent on capture fisheries as their livelihood (Olaño et. al. 2011).
Lagonoy Gulf has been the focus of several projects on the conservation and management of marine resources in the previous years, including people empowerment. However, such initiatives were not enough to address the overexploitation of the resources in the gulf. Hence, there is a great need to improve the awareness of the primary stakeholders in the proper utilization and management of the marine resources.

The result of this assessment will open opportunities to uplift the situation of the fishing industry by providing scientific information that will further develop and improve the existing fisheries policies in sustaining the gulf's resources.

\section{Objectives}

The main objective of this study is to assess the marine fishery resources of Lagonoy Gulf.

Specifically, this study evaluated the effects of the fishing activities by determining the various parameters that could support the status of the gulf:

1. Catch, effort, and catch per unit effort (CPUE) of major gears and their percentage contribution by sector;

2. Catch composition and relative abundance of selected major fish species;

3. Seasonality and length-frequency distribution of dominant species; and, 
Table 1. Estimated annual production (MT) in Lagonoy Gulf (1995-2011)

\begin{tabular}{|c|c|c|c|c|c|c|}
\hline & REA 1995 & 2001 & 2004 & 2008 & 2011 \\
\hline \multicolumn{2}{|c|}{ Municipality/Brgy. } & $15 / 164$ & $15 / 164$ & $15 / 163$ & $15 / 163$ & $14 / 143$ \\
\hline \multicolumn{2}{|c|}{ Fishers } & 7,500 & 8,379 & 8,186 & 9,939 & 9,851 \\
\hline & & No data & 4,315 & 4,275 & 4,679 & 6,043 \\
\hline \multirow{2}{*}{ Boats } & Motorized & \multirow{2}{*}{ No data } & \multirow{2}{*}{4,467} & \multirow{2}{*}{4,551} & 3,207 & 3,641 \\
\hline & Non-motorized & & & & 1,427 & 2,402 \\
\hline \multicolumn{2}{|c|}{ Gear units } & 10,709 & 18,895 & 25,612 & 23,408 & 23,355 \\
\hline \multicolumn{2}{|c|}{ Gear types } & 34 & 22 & 24 & 26 & 29 \\
\hline \multicolumn{2}{|c|}{ Handline } & 5,476 & 12,521 & 17,927 & 18,407 & 12,984 \\
\hline \multicolumn{2}{|c|}{ Gillnets } & 1,965 & 2,601 & 2,727 & 1,645 & 2,734 \\
\hline \multicolumn{2}{|c|}{ Longline } & 427 & 297 & 360 & 277 & 355 \\
\hline \multicolumn{2}{|c|}{ Ringnet } & 0 & 66 & 70 & 69 & 58 \\
\hline \multicolumn{2}{|c|}{ Estimated Production } & 33,380 MT & 36,899 MT & $39,710.26 \mathrm{MT}$ & $34,882.23 \mathrm{MT}$ & $40,332.73 \mathrm{MT}$ \\
\hline
\end{tabular}

4. Population parameters i.e., growth and mortalities, stock sizes, recruitment, and exploitation ratio, of key finfish species.

\section{ME T H O D O L O G Y}

\section{Sampling Site}

Ltf (Figure 1) is considered as one of the largest and most important fishing grounds in the Bicol Region. It is bordered by 15 municipalities covering 165 coastal barangays from the three provinces namely Albay, Camarines Sur, and Catanduanes. It lies approximately from $123^{\circ} 31^{\prime} 37^{\prime \prime}$ E to $124^{\circ} 20^{\prime} 36^{\prime \prime}$ E longitude and $13^{\circ} 44^{\prime} 33^{\prime \prime} \mathrm{N}$ to $13^{\circ} 10^{\prime} 33^{\prime \prime} \mathrm{N}$ latitude. The data collected were from the landing stations of the provinces of Albay and Camarines Sur, considering that landing centers in Catanduanes were established in 2014.

\section{Data Gathering}

Monitoring of catch and effort was done from 1998 to 2012 in the following landing sites: Brgy. Sugod, Tiwi and Tabaco City in Albay; and Brgy. Sabang, San Jose and Brgy. Nato, Sagñay in Camarines Sur. The criteria in choosing the sites were (a) representatives of gears, (b) bulk of landings, (c) willingness of the fisherfolk to cooperate, and (d) accessibility of the site. Monitoring was done every two days, including weekends and holidays. Catch per species, effort exerted, number of boat landings, and length measurements of major species were recorded using the provided standard monitoring form.

\section{Statistical Analysis}

Data on catch composition by gear type, family, relative abundance, gear contribution, and the seasonality of commercially important species were analyzed using the statistical software, MS Excel. The primary data used were the monthly monitored catch landings per species caught by major gears. Catch of minor gears was also recorded to determine the contribution of these gears to the entire production of the gulf.

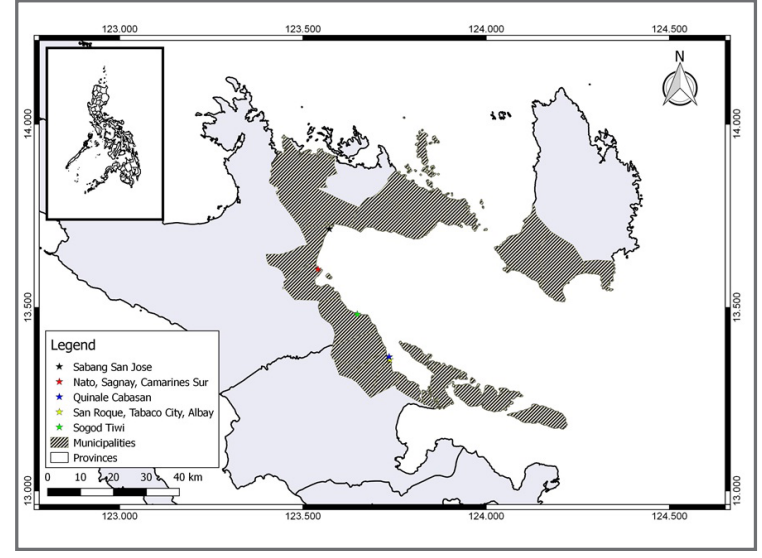

Figure 1. Map of the study area and the landing stations

The following formulas were used in computing the production based on boat and gear inventory:

Estimated Annual Production = CPUE x Annual frequency of operation $\mathrm{x}$ No. of gear units

Estimated Production $=$ CPUE $\mathrm{x}$ Estimated number of boats $\mathrm{x}$ No. of trips

Population parameters [i.e., length infinity $\left(\mathrm{L}_{\infty}\right)$, growth rate $(\mathrm{K})$, recruitment pulse $(\mathrm{RP})$, mortalities $(\mathrm{F}$, $\mathrm{M}$, and $\mathrm{Z}$ ) and exploitation ratio (E)] were estimated using the FAO-ICLARM Stock Assessment Tools (FiSAT) software. Prior to the analysis, the data were first screened for their suitability for analysis based on the presence of exhibited modal progression. Adjustments of class intervals and smoothing of data using running average by three or five were undertaken whenever necessary.

The growth parameter, $\mathrm{L}_{\infty}$, was estimated using the Powell-Wetherall plots; the value of $\mathrm{L}_{\max }$ from the extreme value theorem was used whenever the value of $\mathrm{L}$ was not compelling. The growth constant, $\mathrm{K}$, as described by the Von Bertalanffy Growth Function (VBGF), was generated using the K-scan routine of Electronic Length Frequency Analysis (ELEFAN) I. Optimization of the growth parameters was performed through the other 
options presented in ELEFAN I. The natural mortality (M) was derived from Pauly's $M$ empirical equation, while the total mortality $(\mathrm{Z})$ and fishing mortality $(\mathrm{F})$ were derived from the length-converted catch curve. The number of recruitment pulses (RP) was determined from the decomposition of normal distributions using Hasselblad's NORMSEP.

The relative yield per recruit $\left(\mathrm{Y}^{\prime} / \mathrm{R}\right)$ was generated using the selection ogives of the Beverton and Holt model; the exploitation (E) values from the $\mathrm{Y}$ 'R became the basis for computing the excess catch or fishing mortality based on the equation $\mathrm{E}=\mathrm{F} / \mathrm{Z}$.

\section{RESULTS AND DISCUSSION}

\section{Estimated Annual Production}

The estimated annual production in Lagonoy Gulf ranges from 33,380 MT in 1995 to 40,332.73 MT in 2011. The variation for the estimated production depends on the computed CPUE, number of gears per year, and number of trips per year.

The highest recorded production, which was in 2011, was apparently due to an increase in the number of boats $(23 \%)$ and gears $(10 \%)$, and the presence of purse seine; $51 \%$ of estimated productions were contributed by major gears.

\section{Catch Trend}

\section{Commercial Sector}

Based on the results of the assessment, there was a notable decrease in catch in commercial fishing during the years 2002, 2005, 2008, and 2010-2012 (Figure 2). In 2002 , the decrease was attributed to the declining catch of burirawan (Euthynnus affinis), turingan (Auxis rochei), and pundahan/rayado (Katsuwonus pelamis) by $56 \%, 36 \%$, and $29 \%$, respectively. This can be linked to the decrease also of the catch of Bolinao (Encrasicholina punctifer) that is reported by fishermen, and shifting of target species from small pelagics to large pelagics.

Another notable decline in catch was in 2005, wherein it was attributed to the low production of burirawan (E. affinis) by $68 \%$, bolinao (E. punctifer) by $61 \%$, and pulang buntot (Decapterus tabl) by $55 \%$. This contributed to the $39 \%$ decrease in the total catch of the said sector.

Moreover, the lower production of both finfish and invertebrate species was the reason for a decrease of landed catch in 2008, and was mainly attributed to the typhoons that visited the region such as Frank, Lawin, Marcy, Quinta, Ulysses, and Nina that caused rough sea formation.

From 2010 to 2012, the decreasing catch of tuna, tuna-like, and mackerels of ring net (9\% or $4 \mathrm{MT}$ in 2010 and $21 \%$ or $100 \mathrm{MT}$ in 2011) and Bolinao (E. punctifer) of bag net ( $60 \%$ or 67 MT in 2011 and $34 \%$ or 15 MT in 2012) was attributed to the low landed catch during the said years.

\section{Municipal Sector}

The sudden decline in the catch of bolinao ( $E$. punctifer), matangbaka (Selar crumenophthalmus), and kulambutan (Sepia pharaonis) by $90 \%, 54 \%$, and $10 \%$, respectively, contributed to about $17 \%$ decrease in the 2005 annual production of the municipal sector. Likewise, the small volume of finfishes and invertebrates resulted to the decrease of catch in 2008 of the said sector, due to the occurrences of typhoons.

In general, the catch trend of commercial sector is inceasing, whereas there is a decreasing trend in the municipal sector.

\section{Catch and Effort}

Catch per unit effort (CPUE) is one of the best indicators that show the status of fishery resources in any fishing ground. It can be used as a tool for resource management and ecological management options. Effort was expressed as the total number of boats landed, while CPUE as the total computed catch per boat, expressed in kilograms. Effort and CPUE have close correlation. Generally, the higher the effort, the lower the CPUE, but sometimes it varies, especially when there is abundance of certain species.

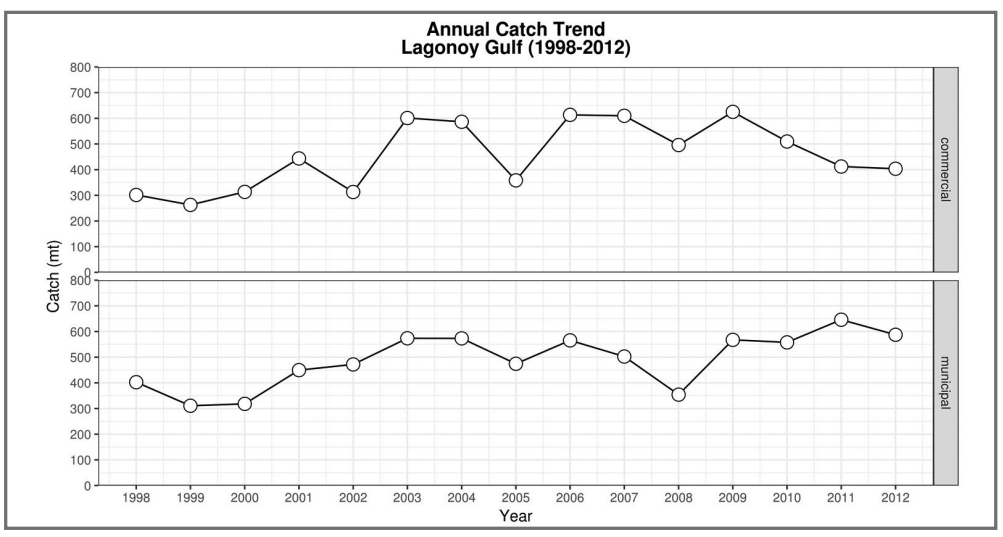

Figure 2. Catch trend in both the municipal and commercial sectors 
The result of the assessment is that the annual average CPUE for commercial sector is $75 \mathrm{~kg}$ per boat, whereas it is $13 \mathrm{~kg}$ per boat for the municipal sector.

\section{Commercial Sector}

Two major gears being used by fishers for commercial fishing were ring net and bag net. In 1998, ring net had a higher CPUE compared to the other years, with a low fishing effort of 2,490 boats (Figure 3 ). The computed annual average effort for this year is 5,647 boats per year, or approximately 16 boats per day; whereas the CPUE is about $67 \mathrm{~kg}$ per boat. The highest recorded effort of this gear was in 2003 with 7,570 boats per year, or about 21 boats per day.

On the other hand, the computed average effort for bag net (Figure 4) was 6,940 boats per year or 19 boats per day; and the computed average CPUE was $181 \mathrm{~kg}$ per boat. In 2003, the abundance of Bolinao (E. punctifer) resulted to the increase in fishing effort.

\section{Municipal Sector}

Handline, gillnet, bottom set longline, and multiple hook and line are the four identified major gears used in municipal waters.

Handline is the most commonly used passive gear designed to catch tuna and other large pelagic species in the gulf. However, most tuna handliners use improvised hooks made from welding rod and firm wires. In addition, the said gear also catches genera of large pelagics such as malasugi (Istiophorus, Makaira, Istiompax) and lamadang/dorado (Coryphaena).

Generally, the effort for this gear is low and increasing, with a corresponding increase in CPUE (Figure 5). There was an abrupt increase in the effort during the year 2009, due to the increase in the abundance of Bangkulis (Thunnus albacares), Iliwon (T. alalunga), and Pundahan (K. pelamis).

Gillnet, on the other hand, catches both demersal and pelagic species. The highest fishing effort of 14,941 boats was recorded in 2002 (Figure 6). Another

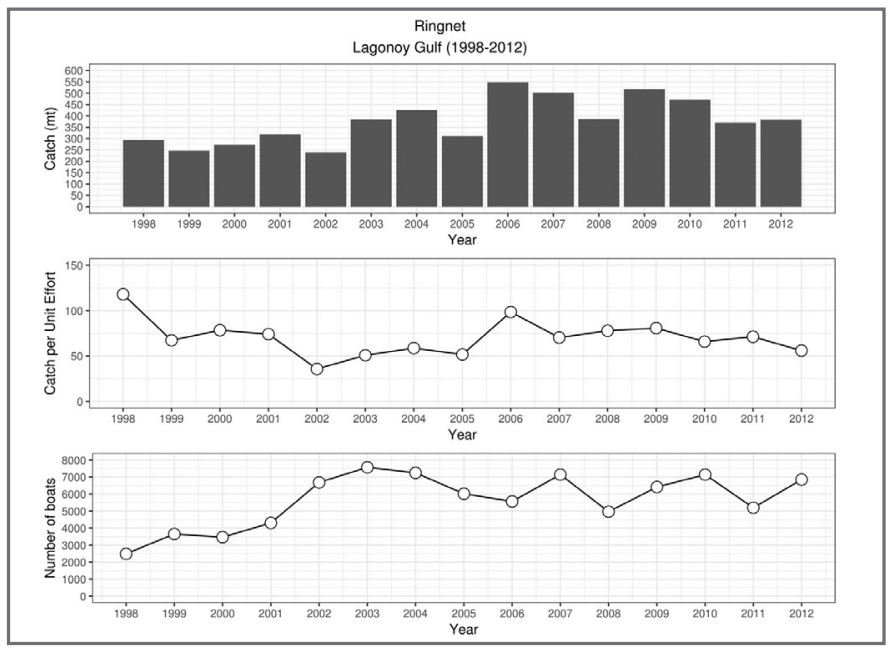

Figure 3. Catch and effort of ringnet in Lagonoy Gulf

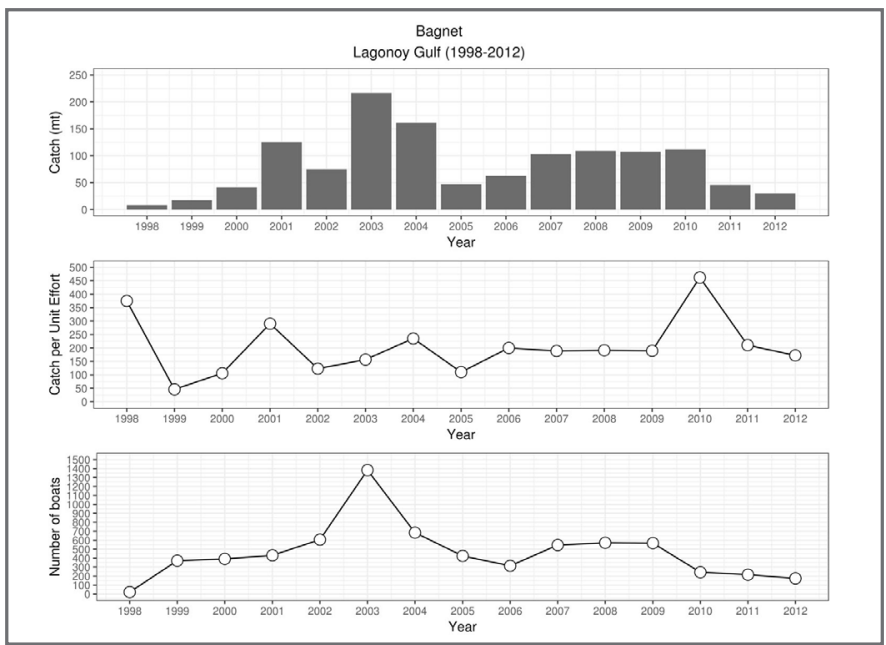

Figure 4. Catch and effort of bagnet in Lagonoy Gulf 


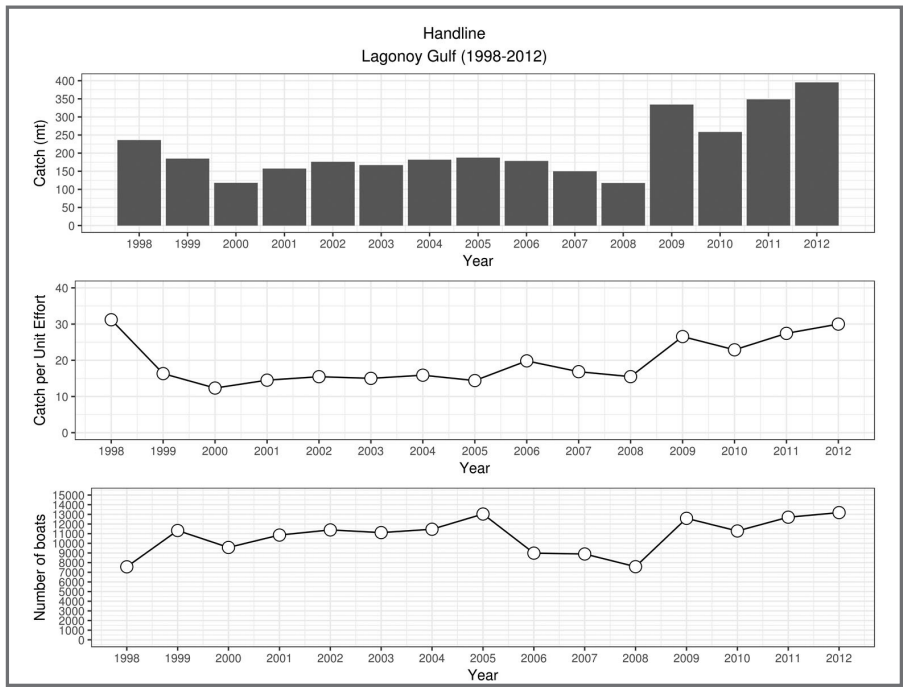

Figure 5. Catch and effort of handline in Lagonoy Gulf

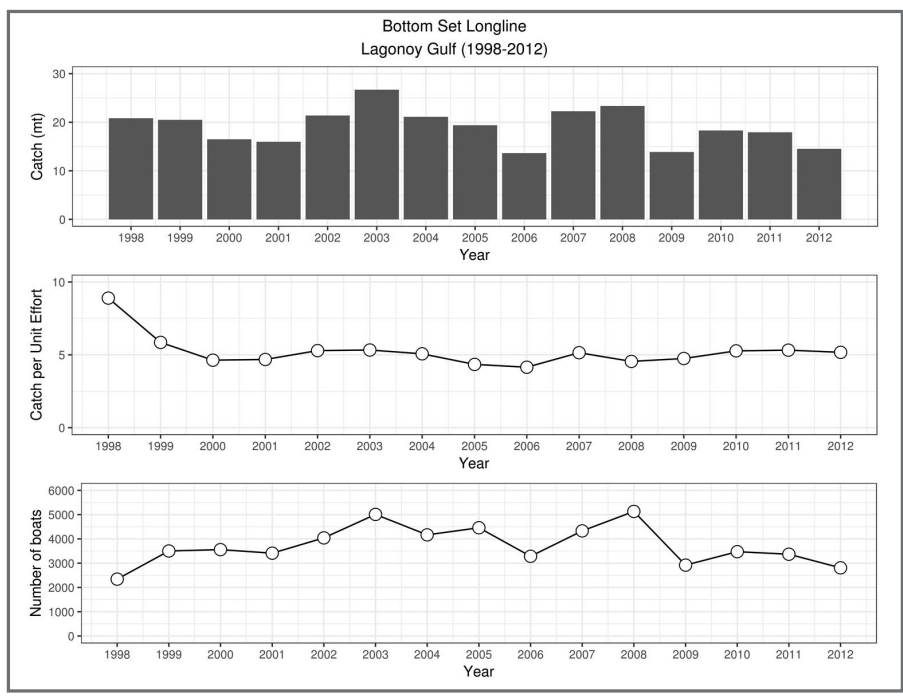

Figure 6. Catch and effort of bottom set longline in Lagonoy Gulf

observation was the effort during the years 1998 and 2012 were low while the CPUEs were higher compared to other years.

Another major gear is the bottom set longline with a computed annual average effort of 3,720 boats per year, whereas the average CPUE is $5 \mathrm{~kg}$ per boat. The highest effort and CPUE (Figure 7) were attributed to the increase of fish and invertebrates of high commercial value such as Scombrids (buraw, hasa-hasa), Carangids (sibubog, talakitok, etc.), Lethrinids (manuping, mangagat, etc.), and Lutjanids (maya-maya)

Lastly, the computed annual average effort of the fishing gear multiple hook and line is 3,580 boats per year while the average CPUE is $4 \mathrm{~kg}$ per boat. Generally, there was a decreasing trend (Figure 8) in the effort of this gear in the gulf.

\section{Catch Composition}

The Lagonoy Gulf is known for its diverse fish and invertebrate resources. The result of the assessment showed that there were a total of 127 families of the aforementioned organisms. Out of this, there are 92 finfish families with 753 species, 17 families of elasmobranchs with 67 species, and 18 families of invertebrates with 55 species. Finfish dominated the catch $(94 \%)$ in the gulf where Bolinao (Engraulidae) has the highest volume of catch $(47 \%)$ as can be seen in Table 2.

Three species dominated the catch in the Lagonoy Gulf for fourteen years, from 1998 to 2012. These were Bolinao (E. punctifer) with a total of about 2,598 MT; Pundahan (K. pelamis), with about 2,547 MT; and Bangkulis (T. albacares) with 1,958 MT, as their contribution to the total volume of catch (Figure 9 and $10)$.

On the other hand, Kugita (Octopus macropus), Kulambutan (S. pharaonis and Sepioteuthis lessoniana) were the top invertebrate resources which contributesd to $264 \mathrm{MT}$ (35\%), $222 \mathrm{MT}$ (30\%), and $119 \mathrm{MT}(16 \%)$ to 
Table 2. Catch composition in Lagonoy Gulf (1995-2011)

\begin{tabular}{|c|c|c|c|c|}
\hline CLASSIFICATION & GROUP & Percentage & Top Family & Percentage \\
\hline \multirow{12}{*}{ 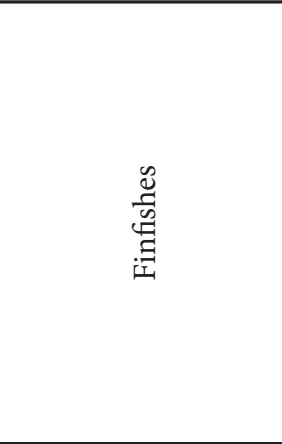 } & \multirow{4}{*}{ Large pelagic } & \multirow{4}{*}{42} & Scombridae & 86 \\
\hline & & & Istiophoridae & 7 \\
\hline & & & Coryphaenidae & 3 \\
\hline & & & Others & 4 \\
\hline & \multirow{4}{*}{ Small pelagic } & \multirow{4}{*}{44} & Engraulidae & 47 \\
\hline & & & Carangidae & 28 \\
\hline & & & Scombridae & 19 \\
\hline & & & Others & 5 \\
\hline & \multirow{4}{*}{ Demersal } & \multirow{4}{*}{9} & Siganidae & 25 \\
\hline & & & Lethrinidae & 19 \\
\hline & & & Belonidae & 12 \\
\hline & & & Others & 44 \\
\hline \multirow{3}{*}{\multicolumn{2}{|c|}{ Elasmobranch }} & \multirow{3}{*}{1} & Carcarhinidae & 39 \\
\hline & & & Dasyatidae & 31 \\
\hline & & & Others & 30 \\
\hline \multirow{3}{*}{\multicolumn{2}{|c|}{ Invertebrates }} & \multirow{3}{*}{5} & Octopodidae & 36 \\
\hline & & & Sepiidae & 32 \\
\hline & & & Others & 32 \\
\hline
\end{tabular}

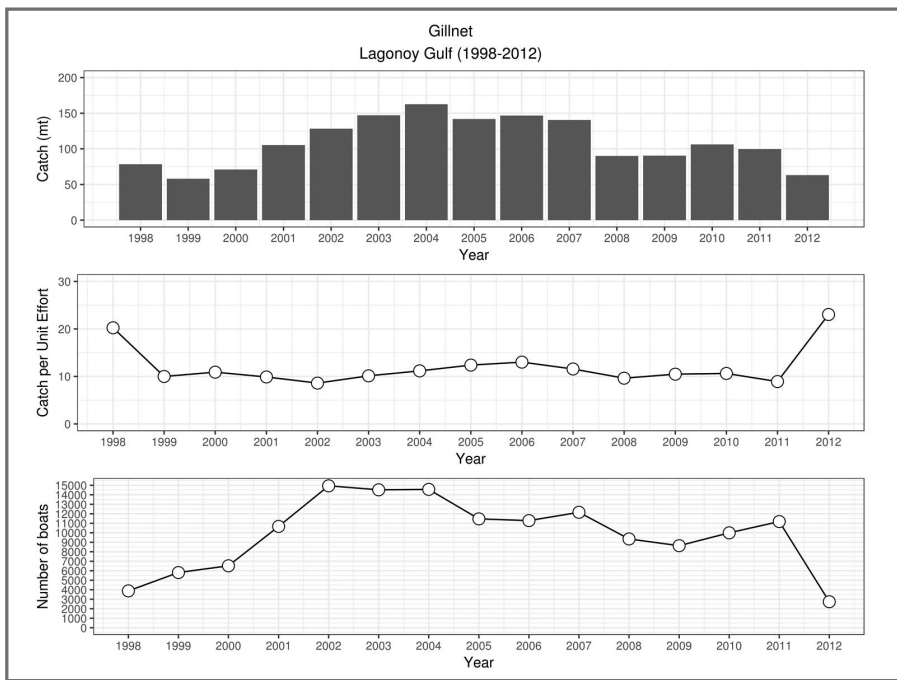

Figure 7. Catch and effort of gillnet in Lagonoy Gulf

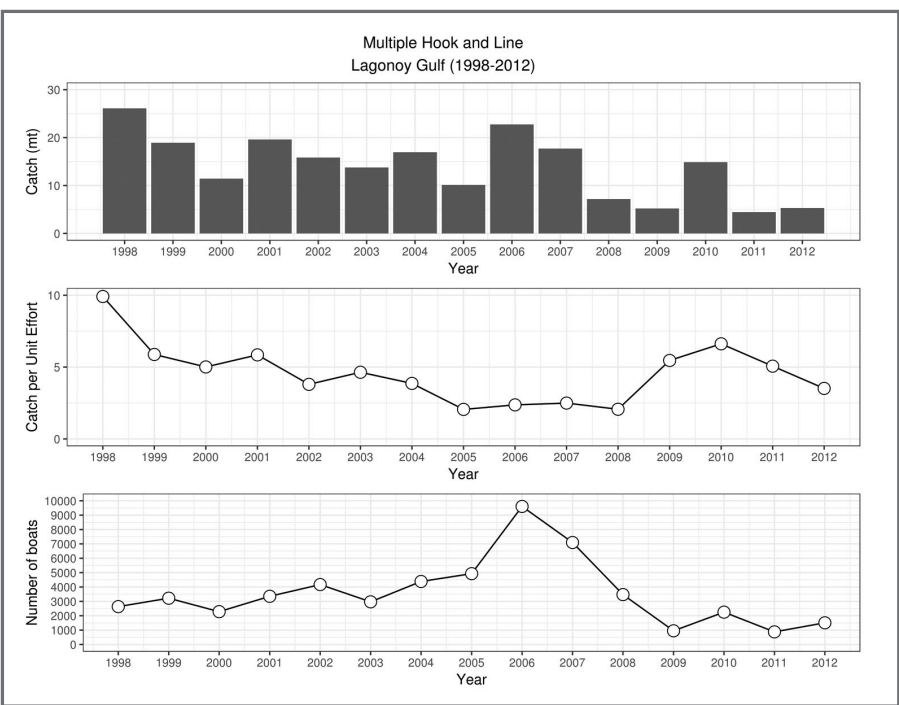

Figure 8. Catch and effort of multiple hook and line in Lagonoy Gulf 
the total catch, respectively. Generally, the production of invertebrates species was declining.

\section{Species Composition by Sector}

Some finfish species were caught by both sectors. Both Pundahan (K. pelamis) and Bolinao (E. punctifer) were largely caught in commercial fisheries. The former had a 33\% (about 2,225.9 MT) share in the catch of the said sector, and only 5\% (321.4 MT) share in the municipal sector. Other tuna-like species and small pelagics were less caught in commercial fisheries. Bangkulis (T. albacares) was the top species caught in the municipal sector, with $29 \%$ production share.

Pusit (Loligo uyii and Nototodarus philippinensis) and Kulambutan (S. lessoniana) are the three dominant invertebrate species caught in the commercial sector with a $50 \%, 27 \%$, and $18 \%$ contribution, respectively. Kugita (O. macropus), on the other hand, is the top invertebrate in the municipal fisheries with $35 \%$ contribution. It was then followed by Kulambutan (S. pharaonis and $S$. lessoniana) with $30 \%$ and $16 \%$, respectively. The most common fishing gear used to catch these species is the jigger, which is operated at night.

\section{Catch Contribution by Major Gears}

The ring net is the major commercial gear operating in Lagonoy Gulf. This gear contributed $83 \%$ or about 5,667.3 MT of the total catch. It is followed by bag net in terms of volume of catch, wherein it contributed $17 \%$ (1,259.2 MT). Pundahan (K. pelamis) and other small pelagic species, particularly Bolinao (E. punctifer), are the predominant species caught by ringnet.

Among the municipal gears, handline contributed the bulk of production (43\%), followed by gillnet (22\%), and other municipal gears with $27.72 \%$ contribution. The higher production of handline is accounted for tuna and other large pelagic species. Small pelagic species dominated the catch of gillnet and multiple hook and line, while the majority of the species caught by bottom set longline included hard demersal species (see Appendix A: Catch Contribution by Major Gears).

\section{Seasonality of Species}

Seasonality of species varies significantly per species and is influenced by monsoon seasons. Variations in the lean and peak months of species caught are influenced by the heavy rains, strong current, wind, and unpredictable gale caused by typhoons and bad weather conditions in the area. In addition, it is also caused by other factors such as occurrence of free school, efficiency of gears used, multi-species interactions, and predatorprey relationships (See Appendix B: Seasonality of Species).

\section{Finfishes}

\section{Large Pelagics}

The occurrence of tuna species, particularly Pundahan (K. pelamis) and Bangkulis (T. albacares), is whole year-around. The peak season of Pundahan ( $K$. pelamis) varies each year. The highest peak was observed in October 2009 with 80 MT, and also in March 2003 with $62 \mathrm{MT}$. The peak of the said species usually occurs during the northeast monsoon (October to March), transition period (April to June), and early and late part of the southwest monsoon which occurs during the months of July to September.

Fishers catch more Bangkulis (T. albacares) during the northeast monsoon and in the early period of the southwest monsoon. The highest peak of the said species was in October 2012 with 59 MT. This species abounds during the southwest monsoon and the first two months of the northeast monsoon.

Iliwon ( $T$. alalunga) is abundant during the months of September to November. The highest peak recorded for this species was in September 2009 with 79 MT which was remarkable compared to other years, then in November 2011 with 38 MT, and October 2012 with 56 MT.

Malasugi (Istiophorus platypterus) occurs all year round, but its abundance is experienced during the transition period (April to May). The highest peak recorded for this species was in May 1998 and April 2003. The lean months are from June to January (northeast and southwest monsoons).

Generally, during the peak season of tuna and other oceanic large pelagic species in the gulf, small pelagic species like Bolinao (E. punctifer) are less abundant. This relationship has been associated with the predation of prey species as food for the large pelagic species. However, in 2003 and 2004, a remarkable bloom of such prey species exceeded the catch of large tuna and oceanic pelagic species, an indication of ecological succession and unbalanced population.

\section{Small Pelagics}

Bolinao (E. punctifer) is the top small pelagic species caught in the gulf. It is abundant during the late period of the southwest monsoon, northeast monsoon, and during transition winds (April to May). During the first five years of this study (1998 to 2002), the peak season of the said species was from February to April, but from 2006 to 2008, it was observed that the peak months shifted to the first three months of northeast monsoon. The highest peak during these years was in December, with production ranging from $120 \mathrm{MT}$ to $159 \mathrm{MT}$.

Another small pelagic species was Matangbaka (S. crumenophthalmus), in which the seasonality occurs whole year round. However, its peak season is experienced during the southwest monsoon and early period of the northeast monsoon. The highest recorded peak of this species was in July 2004 with 37 MT, and also in August 
Table 3. Top fifteen species of finfish in Lagonoy Gulf (1998-2012)

\begin{tabular}{|l|l|c|}
\hline \multicolumn{1}{|c|}{ Species Composition } & Local Name & $\begin{array}{c}\text { Catch } \\
\text { (mt) }\end{array}$ \\
\hline Encrasicholina punctifer & Bolinao & 2598 \\
\hline Katsuwonus pelamis & $\begin{array}{l}\text { Pundahan, } \\
\text { Rayado }\end{array}$ & 2547 \\
\hline Thunnus albacares & $\begin{array}{l}\text { Bangkulis, } \\
\text { Kikyawon }\end{array}$ & 1958 \\
\hline Selar crumenophthalmus & Matambaka & 750 \\
\hline Rastrelliger faughni & Buraw & 443 \\
\hline Thunnus alalunga & $\begin{array}{l}\text { Bangkulis, } \\
\text { Iliwon }\end{array}$ & 428 \\
\hline Decapterus russelli & Sibubog & 369 \\
\hline Istiophorus platypterus & Malasugi & 358 \\
\hline Euthynus affinis & Burirawan & 281 \\
\hline Stolephorus sp. & Bolinao & 279 \\
\hline Rastrelliger kanagurta & Buraw & 187 \\
\hline Auxis thazard & Turingan lapad & 172 \\
\hline
\end{tabular}

2007 with 17 MT; the lean months were during the late period of the northeast monsoon and transition period.

Lastly, buraw (Rastrelliger faughni), another small pelagic species, is abundant during the southwest monsoon and early part of the northeast monsoon. The highest recorded peak of this species was in October 2006 to September 2010 with an average production of $12 \mathrm{mt}$. There were no observed changes in the occurrence of this species although the catch during the peak seasons varied in all years of the study.

\section{Invertebrates}

Kugita (O. macropus) is the top invertebrate species which comprises $35 \%$ of the total landed catch in Lagonoy Gulf. The occurrence of this species is during the late period of transition and southwest monsoon and early period of the northeast monsoon; the remaining months are lean months for this species. The highest peaks were in the months of May from 2006 onwards, with a range from 3 to $7 \mathrm{MT}$.

For kulambutan (S. lessoniana), the highest occurrence is during the northeast monsoon and early period of the southwest monsoon. Transition periods are the lean months for this species. The three highest recorded peaks were in October and November 2006, and in July 2007 with 2 MT each. This species had a greater catch during this period compared to that obtained during the first five years of the study.

\section{Elasmobranchs}

The occurrence of Pagi (Dasyatis kuhlii) is whole year-round, but its peak season is experienced during the northeast monsoon and transition period; the lean months are July to September, during the southwest monsoon. The highest peak was in November 1998. The
Table 4. Top ten species of invertebrates in Lagonoy Gulf (1998-2012)

\begin{tabular}{|l|l|c|}
\hline \multicolumn{1}{|c|}{ Species Composition } & Local Name & $\begin{array}{c}\text { Catch } \\
(\mathbf{m t})\end{array}$ \\
\hline Octopus macropus & Kugita & 264 \\
\hline Sepia pharaonis & Kulambutan & 222 \\
\hline Sepioteuthis lessoniana & Kulambutan & 119 \\
\hline Portunus pelagicus & Kasag & 45 \\
\hline Sepia lycidas & Kulambutan & 16 \\
\hline Panulirus penicillatus & Banagan & 15 \\
\hline Loligo uyii & Pusit & 13 \\
\hline Parribacus antarcticus & Banagan & 9 \\
\hline Portunus sanguinolentus & Kasag & 8 \\
\hline Panulirus longipes longipes & Banagan & 7 \\
\hline
\end{tabular}

abundance of shark species such as pating (Carcharhinus sp., Prionace glauca) varies significantly with each year. They usually appear during the southwest monsoon, transition period and late northeast monsoon. Pating (Carcarhinus sp.) peaks during the months of April and July; the highest catch records were in July 1999 (643 kg), April 2002 (451 kg), May 1999 (437 kg), and July 2001 (434 kg). The highest peaks for pating (Prionace glauca) were in January 2004 (489 kg) and also in 2009 (277 $\mathrm{kg}$ ). Lean months for this species can be associated with the strong winds, current and rainy season in the Bicol region.

\section{Length Frequency Distribution}

Pundahan (K. pelamis) was caught by ring net and handline from $90 \%$ to $95 \%$ below length at first maturity (Lm), either in free school or in fish aggregating devices (FADs). Handline caught mostly small-sized bangkulis (Thunnus albacares) with $67 \%$ below Lm. Other tuna-like species such as burirawan (E. affinis), and turingan (Auxis thazard and $A$. rochei) caught by ringnet were immature, $57 \%$ to $96 \%$ of which were below $\mathrm{Lm}$.

Small pelagic species, such as Matangbaka ( $S$. crumenophthalmus), were commonly caught by three major gears, namely ring net, gillnet, and multiple hook and line. The gillnet had the highest catch of juveniles, $91 \%$ below Lm. Buraw (Rastrelliger kanagurta), caught by ring net, was also of small sizes, $81 \%$ juveniles; while gillnet caught mostly bigger-sized species. Ring net caught $98 \%$ of small-sized pelagic species; gillnet, $84 \%$ below Lm. Ring net and handline contributed to the exploitation of juvenile species in the gulf. Handliners using hooks above No. 566 and gillnet with less than $3 \mathrm{~cm}$ mesh sizes caught small-sized fish or juveniles still incapable to breed, reproduce, and contribute to the fish biomass. Ring net, mostly operating in FADs in municipal waters, exploits more of the juveniles of pelagic species or species caught before they sexually mature.

${ }^{*}$ Lengths at first maturity of species were extracted from FishBase (See Appendices: Figures 21-30) 


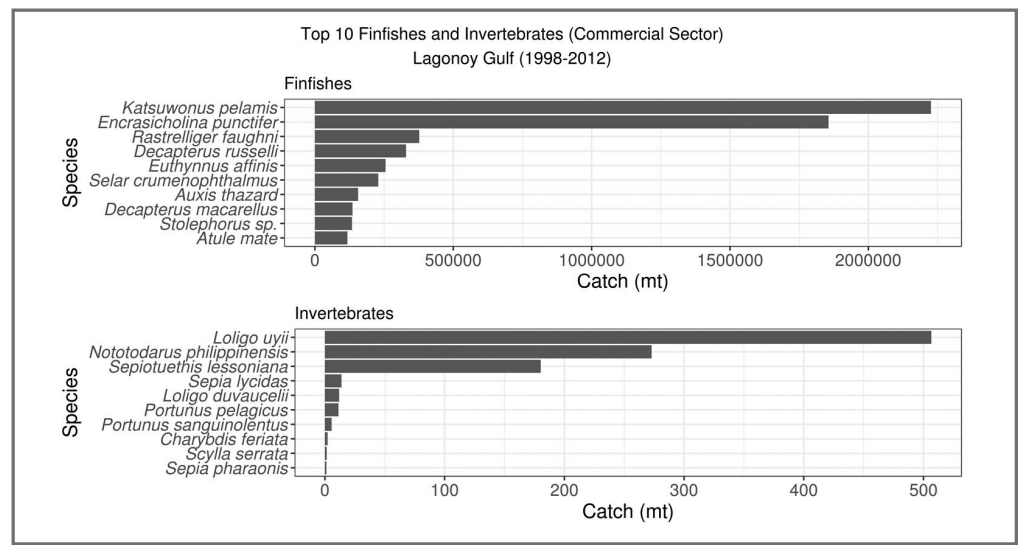

Figure 9. Top ten species of finfish and invertebrates caught by commercial sector in Lagonoy Gulf (1998-2012)

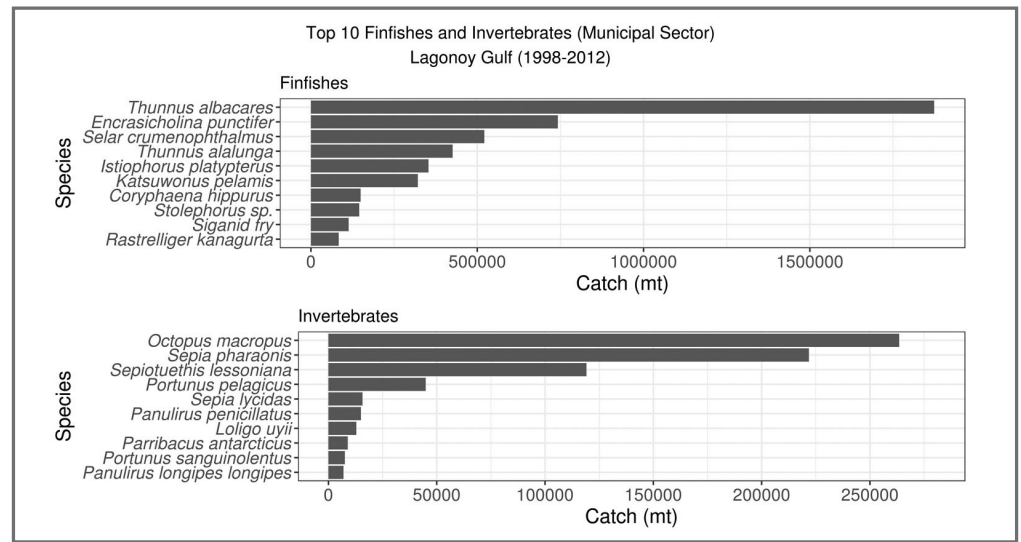

Figure 10. Top ten species of finfish and invertebrates caught by municipal sector in Lagonoy Gulf (1998-2012)

\section{Estimation of Population Parameters}

\section{Growth}

The length infinity $\left(\mathrm{L}_{\infty}\right)$ and growth curve $(\mathrm{K})$ values were relatively high, indicating that the species studied were short-lived and relatively fast-growing. $\mathrm{L}_{\infty}$ values ranged from 24.92 for sibubug (D. russelli) to 52.81 for turingan (A. thazard); and $\mathrm{K}$ values ranged from 0.85 for turingan (A. thazard) to 1.34 for buraw ( $R$. kanagurta). The growth performance indices ( $)$, which are a function of the $\mathrm{L}_{\infty}$ and $\mathrm{K}$ values of individual species, were comparable with their standards in other fishing grounds in the Philippines (Table 5).

\section{Mortality}

The high mortality coefficients (Z), which ranged from 7.02 for matangbaka (S. crumenophthalmus) to 13.13 for buraw ( $R$. faughni), indicated a high turnover rate of biomass but low survival rates, considering also that the estimates obtained for the fishing mortalities (F) were higher than the values of natural mortality (M) (Sia III et al. 1995). The mortality of a cohort was due to fishing mortality (F) and natural mortality (M), caused by destructive fishing gears and fishing operation, predation, diseases, and death due to aging.

\section{Recruitment Pulses}

This gives an idea of how many times within a year young batches of fishes become available in the fishing ground. Most of the species in Lagonoy Gulf are unimodal or have one recruitment peak. This varies sometimes to bimodal in a specified year, due to the two major monsoon pulses in the Philippines (Pauly 1984).

\section{Exploitation Rate}

The exploitation values 0.3 to 0.5 are the $E$ values of maximizing biological yield (Pauly 1984). The standard E value is 0.5 , and if the value obtained is lower than 0.5 , the stock is still unexploited beyond its optimum yield.

The dominant small pelagic species investigated gave higher E values, from 0.69 for buraw (R. faughni) to 0.84 for turingan (A. thazard) and for pundahan (K. pelamis). Matangbaka (S. crumenopthalmus), buraw $(R$ faughni), and sibubog (D. russelli) had higher $\mathrm{F}$ values $(0.79,0.80$, and 0.77 , respectively), but their declining trend were implicating recovery period. All the species analyzed gave high mean exploitation level of 0.77 , which is quite alarming. It is an indication that the fishery resources of the gulf are continually experiencing heavy fishing pressure due to unsustainable fishing practices. The exploitation values for 15 years were much higher 
Table 5. Population parameters of commercially important pelagic species in Lagonoy Gulf (2001-2002)

\begin{tabular}{|c|c|c|c|c|c|c|c|c|c|}
\hline Species & Gear & $\mathrm{L} \infty$ & $\mathbf{k}$ & Ø' & $\mathbf{M}$ & $F$ & $\mathbf{Z}$ & $\mathbf{E}$ & RP \\
\hline Selar crumenophthalmus & $\mathrm{RN}$ & 28.79 & 1.18 & 2.98 & 1.95 & 7.49 & 9.89 & 0.80 & 1 \\
\hline Selar crumenophthalmus & $\mathrm{GN}$ & 27.71 & 1.08 & 2.92 & 1.93 & 7.80 & 9.73 & 0.79 & 1 \\
\hline Selar crumenophthalmus & MHL & 27.74 & 1.09 & 2.92 & 1.93 & 5.09 & 7.02 & 0.72 & 1 \\
\hline Rastrelliger kanagurta & $\mathrm{RN}$ & 28.75 & 1.34 & 3.04 & 2.19 & 6.92 & 9.11 & 0.75 & 1 \\
\hline Rastrelliger kanagurta & GN & 29.69 & 1.23 & 3.02 & 2.04 & 5.20 & 7.24 & 0.70 & 1 \\
\hline Rastrelliger faughni & $\mathrm{RN}$ & 26.00 & 1.32 & 2.95 & 2.23 & 5.62 & 7.85 & 0.69 & 1 \\
\hline Rastrelliger faughni & $\mathrm{GN}$ & 26.25 & 1.41 & 2.98 & 2.32 & 10.82 & 13.13 & 0.80 & 2 \\
\hline Decapterus russelli & $\mathrm{RN}$ & 24.92 & 0.95 & 2.77 & 1.82 & 6.90 & 8.72 & 0.77 & 1 \\
\hline Decapterus macrosoma & $\mathrm{RN}$ & 26.22 & 1.14 & 2.89 & 2.02 & 7.52 & 9.53 & 0.76 & 1 \\
\hline Auxis thazard & $\mathrm{RN}$ & 52.81 & 0.85 & 3.37 & 1.37 & 8.65 & 10.02 & 0.84 & 1 \\
\hline Auxis rochei & $\mathrm{RN}$ & 47.24 & 0.69 & 3.19 & 1.24 & 4.24 & 5.48 & 0.74 & 1 \\
\hline Atule mate & $\mathrm{RN}$ & 28.51 & 1.18 & 2.98 & 2.02 & 9.89 & 11.91 & 0.80 & 1 \\
\hline Atule mate & GN & 29.45 & 1.07 & 2.96 & 1.88 & 6.04 & 7.92 & 0.75 & 1 \\
\hline Katsuwonus pelamis & $\mathrm{HL}$ & 94.64 & 0.65 & 3.76 & 0.98 & 5.73 & 6.71 & 0.84 & 1 \\
\hline
\end{tabular}

than the results of REA (Sia III et al. 1995) and resource stock assessment (Olaño et al. 2009).

\section{Summary}

The primary results of the study showed that the catch composition of the gulf was dominated by small pelagic fishes $(43.83 \%)$, whereas the large pelagics contributed $42.18 \%$, and the demersal fishes shared $13.94 \%$. Seasonality of the species showed variations the whole year round depending on the species but was mainly affected by monsoon seasons. In addition, $89 \%$ to $98 \%$ of the small pelagic species were caught below their length-at-first maturity (Lm). Their vulnerability to ring net, gillnet (less than $3 \mathrm{~cm}$ mesh) and multiple hook and line (hooks above No. 566) resulted to growth and recruitment overfishing.

Analysis of growth and mortality parameters of small pelagics suggested that these species were shortlived and relatively fast-growing, as indicated by a high growth curve $(\mathrm{K})$ values which ranged from 0.85 to 1.34 . Total mortality coefficients ( $Z$ ) had an average of 9.29 , substantiated with a high turnover of biomass but low survival rate due to the excessive fishing effort. Computed exploitation values (E) were all far beyond the optimum level of exploitation which is 0.5 ; the values obtained ranged from 0.69 to 0.84 .

Matangbaka (Selar crumenophthalmus), Buraw (Rastrelliger faughni), and Sibubog (Decapterus russelli) had higher E-values, but their declining trend was implicating recovery period.

Active gears, particularly ring net, were the gears that exploit more of the resources in terms of catch volume and sizes of the species caught. Excessive fishing effort and growth overfishing led to an overexploitation of the gulf's resources and adversely affected subsequent recruitment of pelagic species.

\section{CONCLUSION AND RECOMMENDAT I ON S}

\section{Conclusion}

Lagonoy Gulf is overfished due to heavy fishing pressure and growth overfishing. Unsustainable fishing practices due to unregulated use of fishing gears are continuously depleting the fishery resources in Lagonoy Gulf.

\section{Recommendations}

To address the problems of overfishing and other unsustainable fishing practices in Lagonoy Gulf, the following measures are recommended based on the suggestions of the fisherfolk sector during the validation of the study:

1. Lessen the number of boats per gear operating in the gulf through:

a. Color coding scheme and observation of fishing holiday upon public consultation;

b. Enforcement of the existing municipal fisheries ordinances in all coastal municipalities that could support fisheries management action for the entire gulf;

c. Strong enforcement of fishery laws specifically FAO 201 (Ban of Fishing with Active Fishing Gears in Municipal Waters, Bays, and Fishery Management Area) and FAO 198 (Rules and Regulation on Commercial Fishing); and

d. Proper management and regulation of Fish Aggregating Devices (FADs);

2. Increase the visibility of LGU Bantay-Dagat and assistance of BFAR Fishery Law Enforcement Team to the LGUs;

3. Restriction of fishing gears that are highly exploitative for key species such as hook and line 
and multiple hook and line that use small hooks (\#655 above), and gillnets that use $3 \mathrm{~cm}$ mesh size below;

4. Total eradication of commercial fishing gears operating in the municipal waters;

5. Expansion and establishment of Marine Protected Areas (MPAs) in all coastal municipalities surrounding the gulf to support the productivity of the marine habitats.

\section{R E F E R E N C E S}

Barut NC, Santos MD, Garces LR. 2004. Overview of the Philippine marine fisheries. In Turbulent Seas: The Status of Philippine Marine Fisheries, p. 22-31. CRMP, Cebu City, Philippines. p. 378.

BFAR V. 2012. Fisheries and Aquatic Resources Management Council (FARMC) - PMC Report. Bureau of Fisheries and Aquatic Resources (BFAR) Regional Office No. 5, San Agustin, Pili, Camarines Sur.

Olaño VL, Vergara MB, Gonzales FL. 2009. Assessment of the fisheries of Lagonoy Gulf (Region5), Bureau of Fisheries and Aquatic Resources, Regional Office No.5, San Agustin, Pili, Camarines Sur, Philippines. Bureau of Fisheries and Aquatic Resources, Technical Paper Series. Vol. 12 No.5. 3rd Floor PCA Bldg., Elliptical Rd., Diliman, Quezon City, Philippines/ National Fisheries Research and Development
Institute, 940 Kayumanggi Bldg., Quezon Avenue, Q.C., Philippines.

Pauly D. 1984. Fish population dynamics in tropical waters: a manual for use with programmable calculators. ICLARM Studies and Reviews 8: 325.

Pelea NR, Borbe SG, Pelea MJD. 2005. Socio-economic status of fisherfolks in Lagonoy Gulf, pp. 1-98. In: Soliman, V.S., R.R. Dioneda, Sr., and N.R. Pelea (eds). 2005. Lagonoy Gulf Post-Resource and Socioeconomic Assessment. Final Report Submitted to the Fishery Resource Management Project, Department of Agriculture-Bureau of Fisheries and Aquatic Resources, Quezon Avenue, Quezon City. Bicol Small Business Institute Foundation, Inc., Bicol University Main Campus, Legazpi City. p. 306.

Sia QP, Garces LR, Silvestre GT. 1995. Population parameters and exploitation ratios of selected fishes caught in Lagonoy Gulf, Philippines. In: G. Silvestre, C. Luna, V. Soliman and L. Garces (eds.), Resources and Ecological Assessment of Lagonoy Gulf, Philippines. ICLARM Tech. Rep.

Soliman VS, Nieves P, Garces LR, Sia QP III. 1995. Catch and effort in Lagonoy Gulf, Philippines. In: G. Silvestre, C. Luna, V. Soliman and L. Garces (eds.), Resources and Ecological Assessment of Lagonoy Gulf, Philippines. ICLARM Tech. Rep. 
APPENDICES

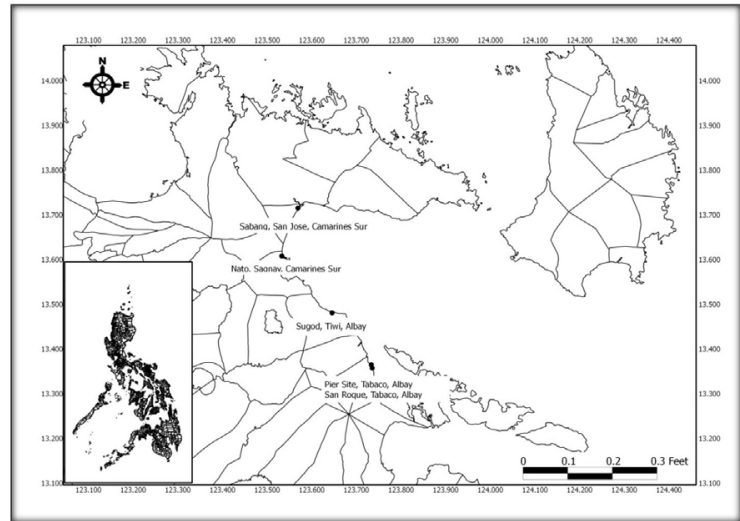

Figure 1. Map of the study area and its related information.

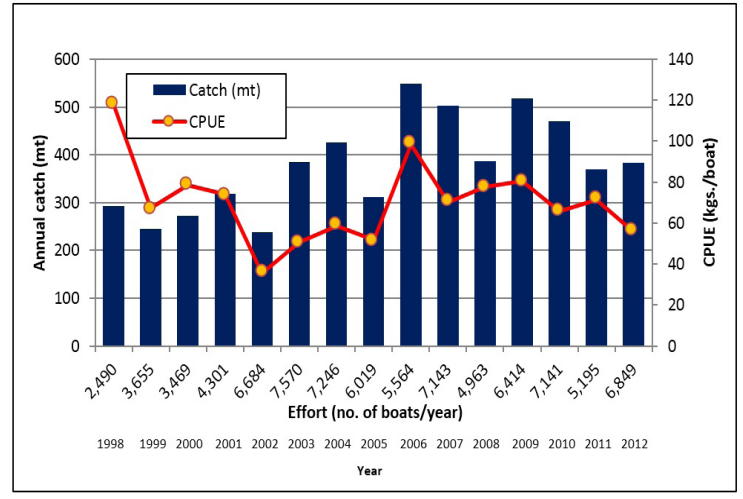

Figure 3. Relationship of catch and effort in Lagonoy Gulf (1998-2012)

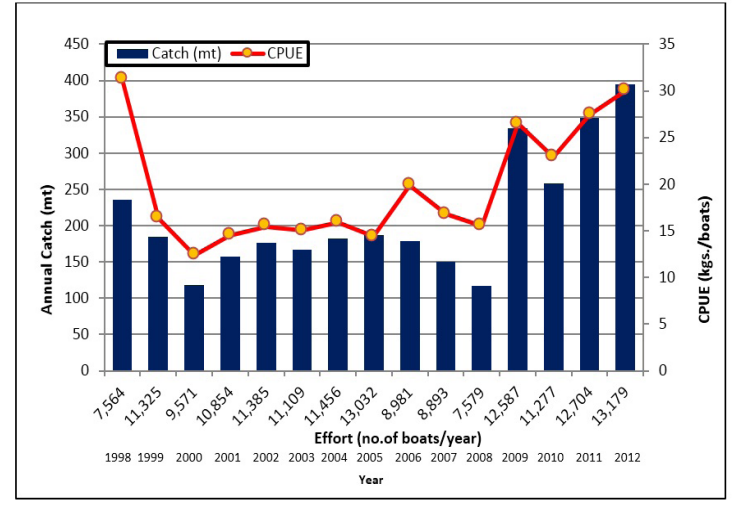

Figure 5. Relationship of catch and effort in Lagonoy Gulf (1998-2012)

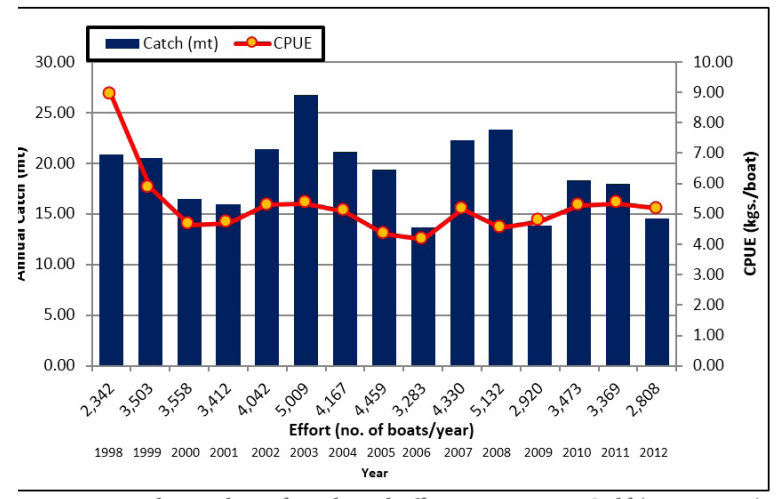

Figure 7. Relationship of catch and effort in Lagonoy Gulf (1998-2012)

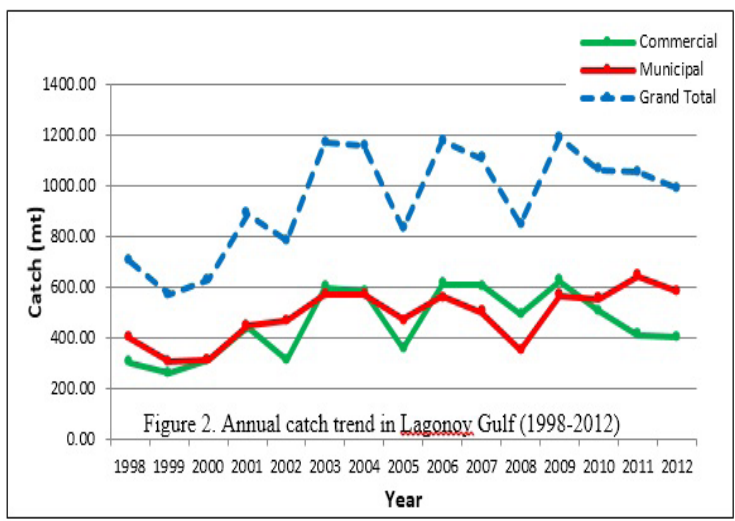

Figure 2. Annual catch trend in Lagonoy Gulf (1998-2012)

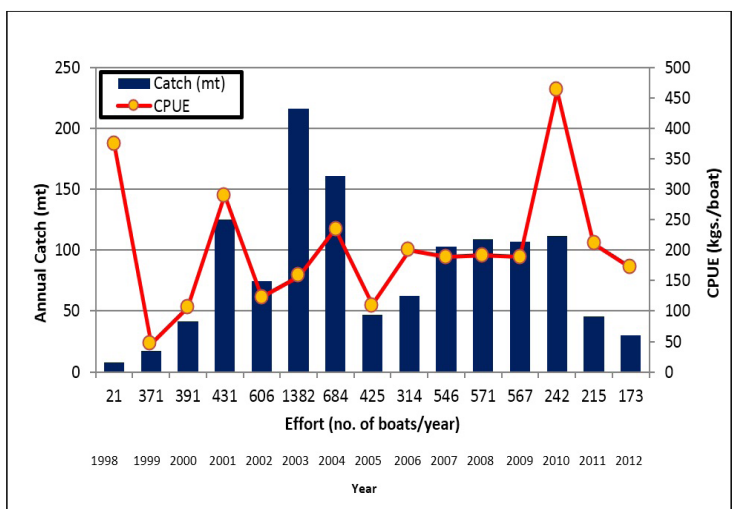

Figure 4. Relationship of catch and effort in Lagonoy Gulf (1998-2012)

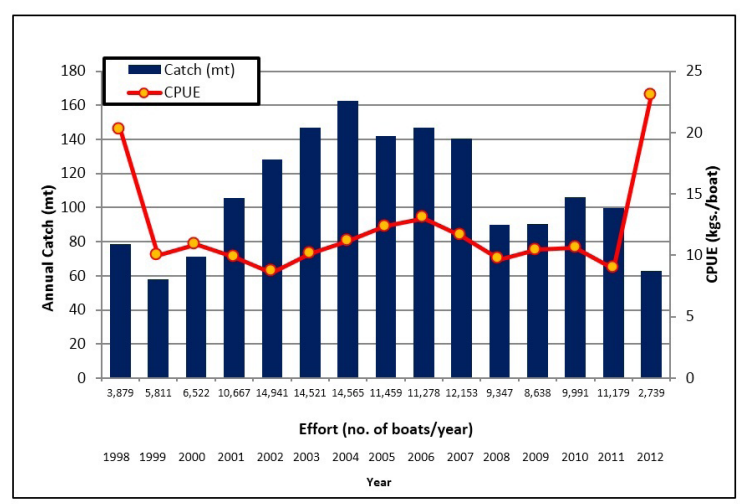

Figure 6. Relationship of catch and effort in Lagonoy Gulf (1998-2012)

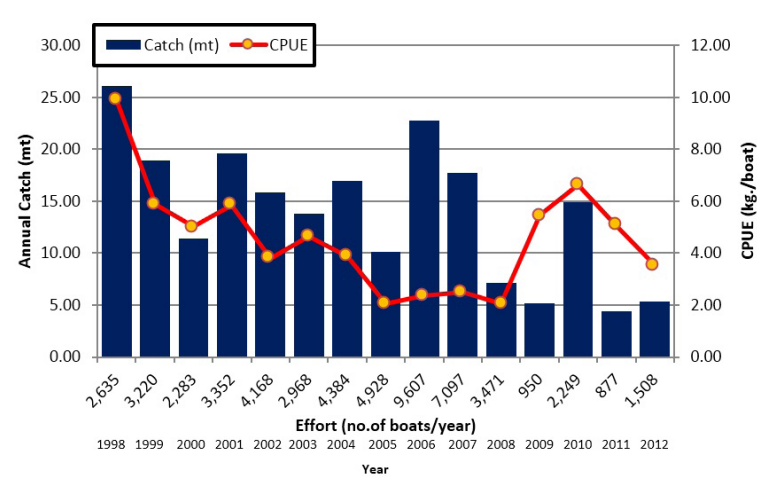

Figure 8. Relationship of catch and effort in Lagonoy Gulf (1998-2012) 


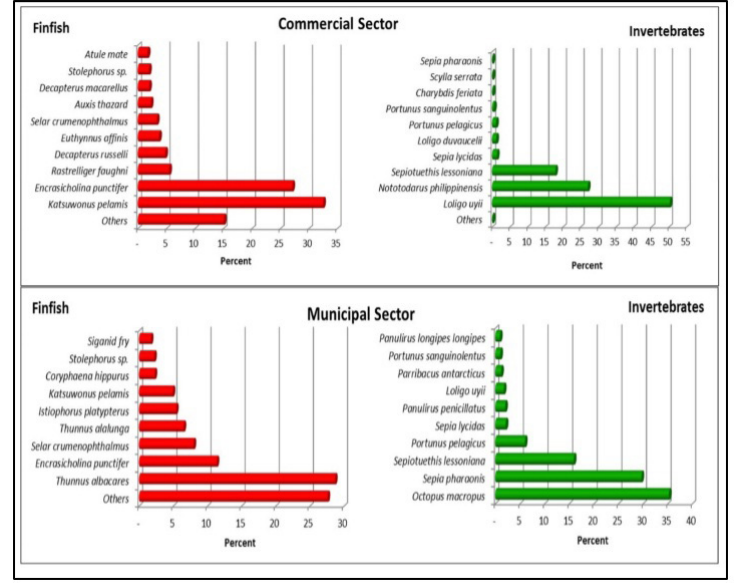

Figure 9. Percentage composition of finfish and invertebrate species by sector in Lagonoy Gulf (1998-2012)

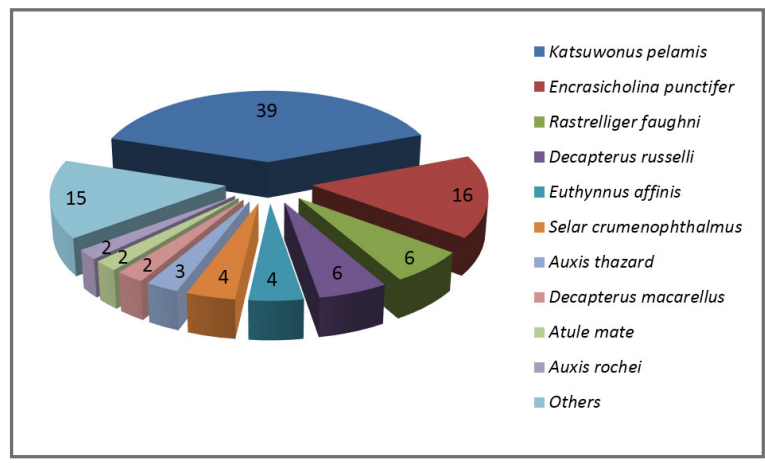

Figure 11. Percentage catch composition of ringnet in Lagonoy gulf (1998-2012)

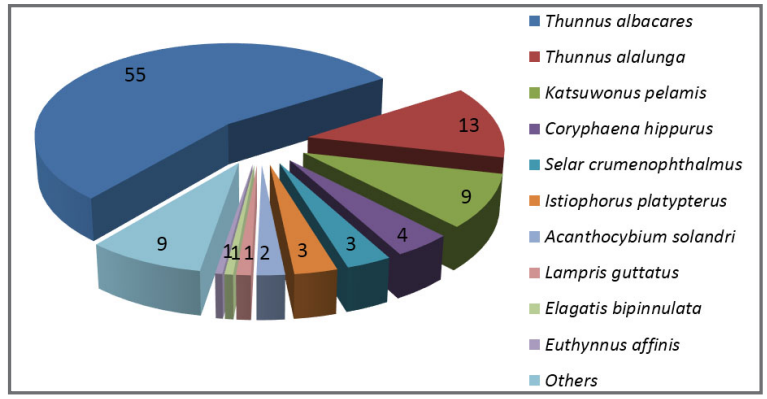

Figure 13. Percentage catch composition of handline in Lagonoy gulf (1998-2012)

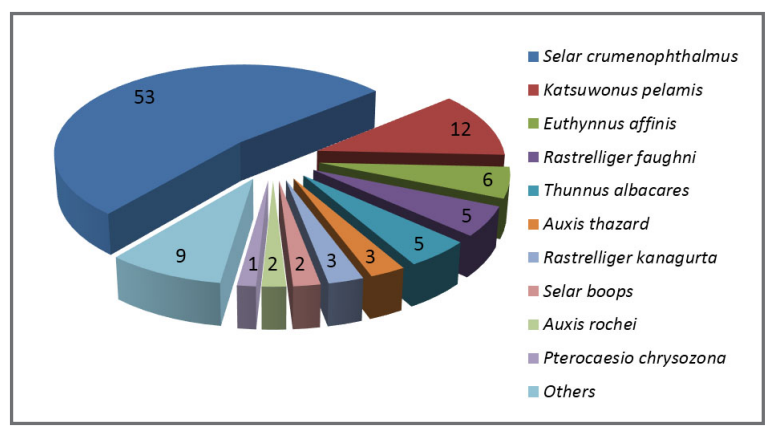

Figure 15. Species composition of Multiple Hook and Line

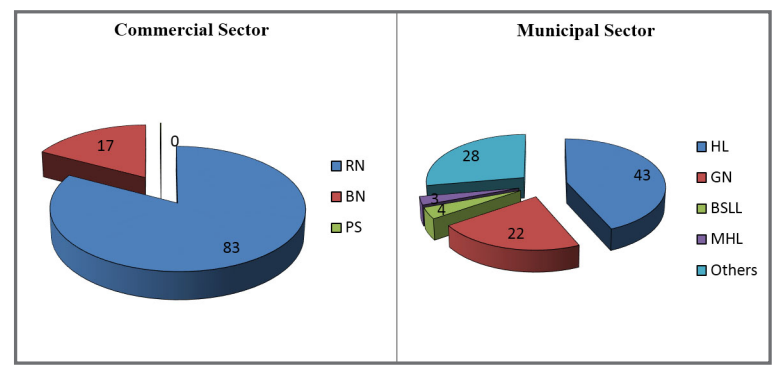

Figure 10. Percentage catch of Commercial and Municipal gears in Lagonoy Gulf (1998-2012)

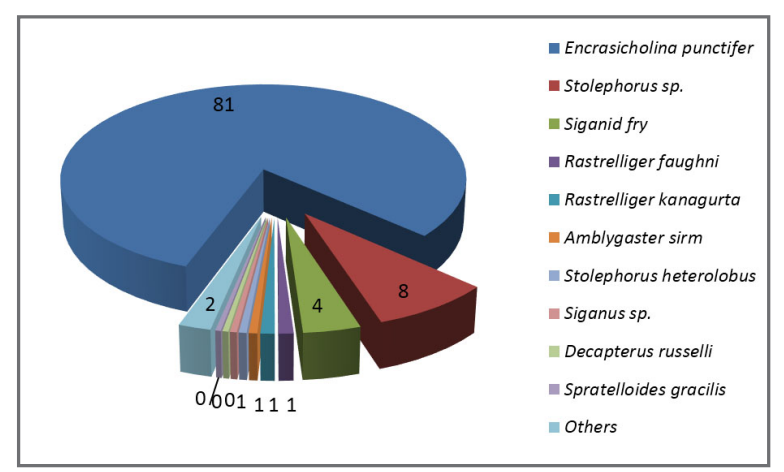

Figure 12. Percentage catch composition of bagnet in Lagonoy gulf (1998-2012)

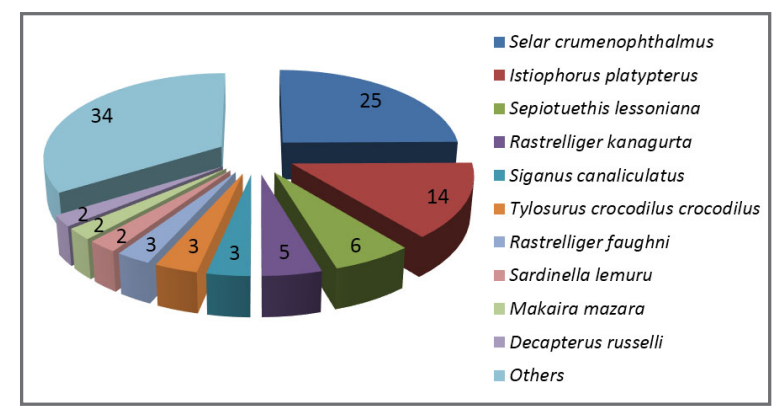

Figure 14. Species composition of Gillnet

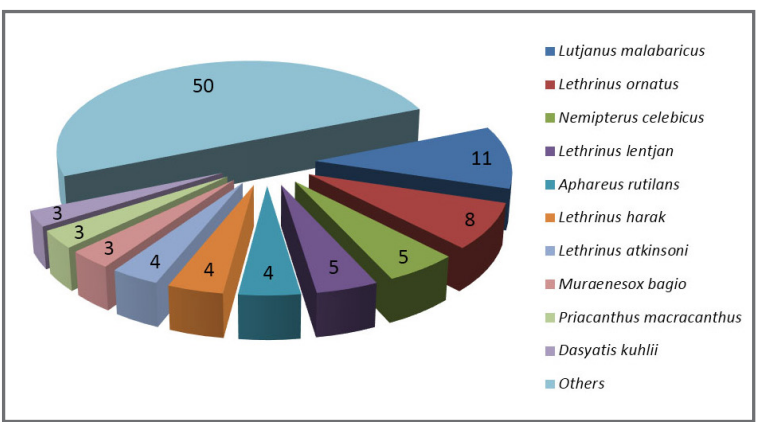

Figure 16. Species composition of Bottom set long line 


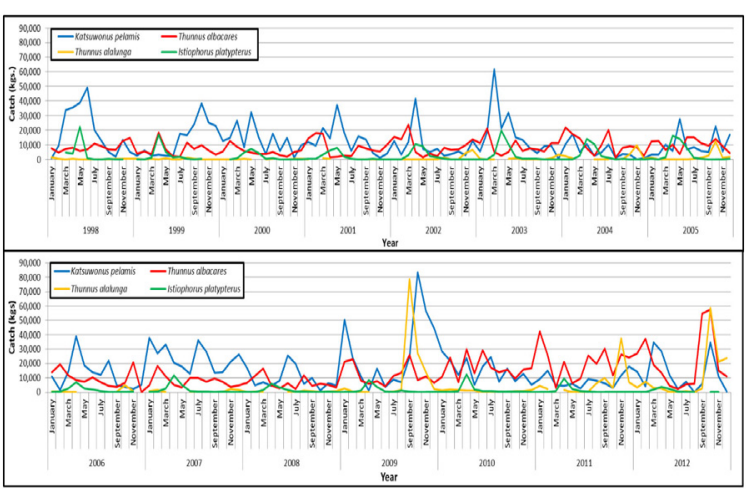

Figure 17. Seasonality of Large pelagic species in Lagonoy Gulf (1998-2012)

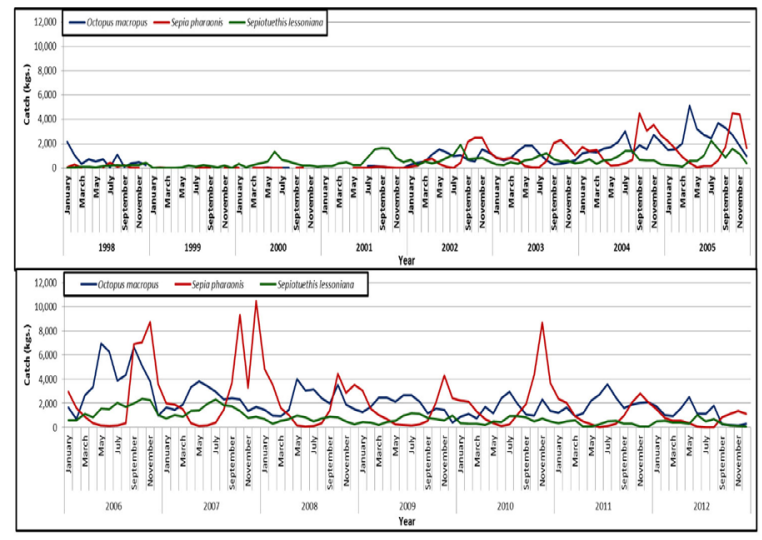

Figure 19. Seasonality of Invertebrate species in

Lagonoy Gulf (1998-2012)

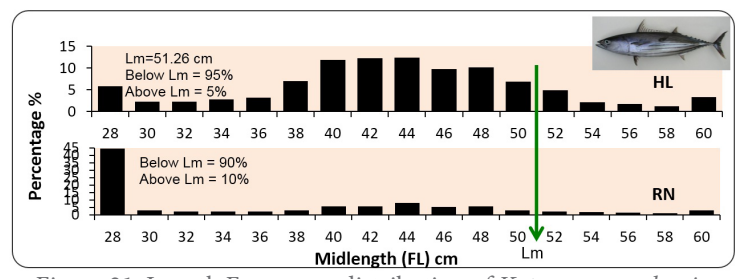

Figure 21. Length Frequency distribution of Katsuwonus pelamis (2001-2012)

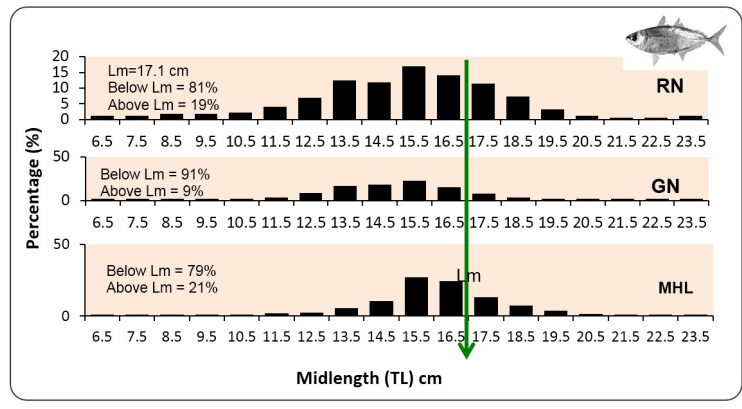

Figure 23. Length Frequency distribution of Selar crumenophthalmus

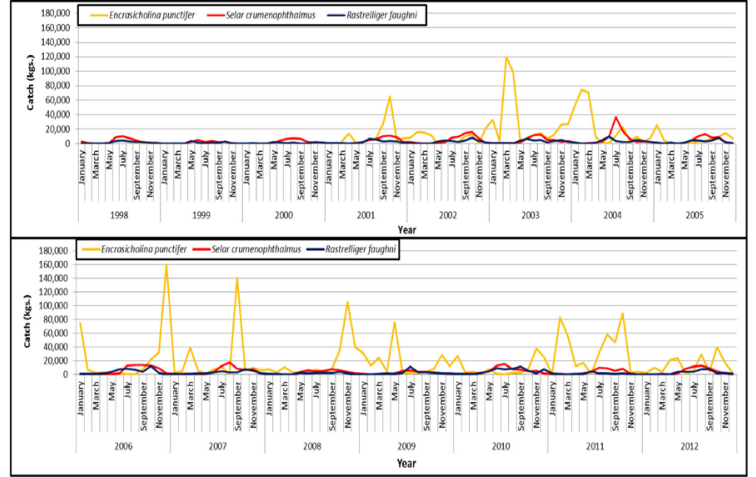

Figure 18. Seasonality of Small pelagic species in Lagonoy Gulf (1998-2012)

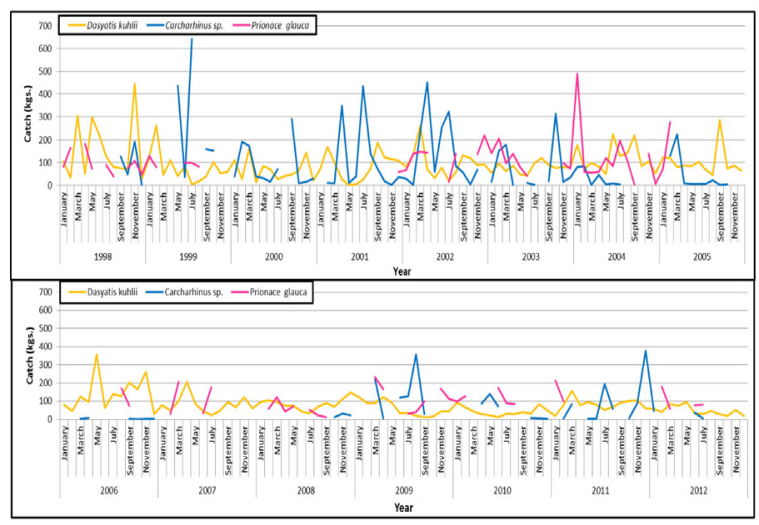

Figure 20. Seasonality of Elasmobranch species in

Lagonoy Gulf (1998-2012)

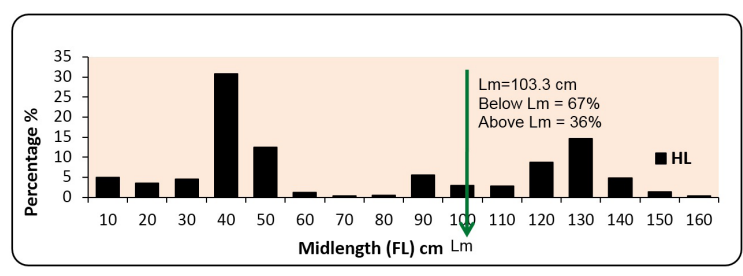

Figure 22. Length Frequency distribution of Thunnus albacares (2001-2012)

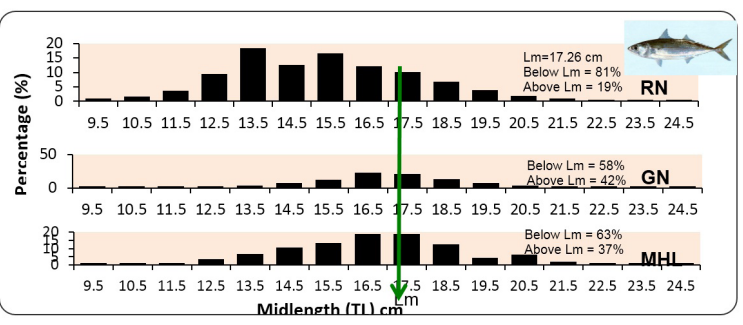

Figure 24. Length Frequency distribution of Rastrelliger kanagurta (2001-2012) 


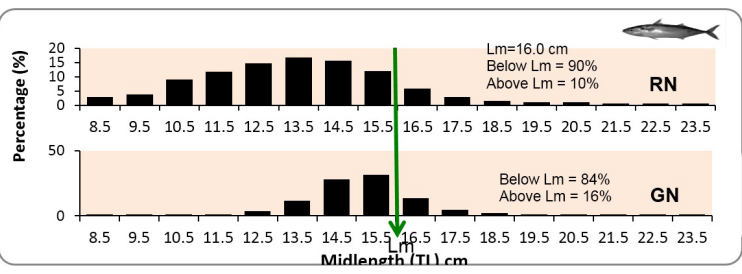

Figure 25. Length Frequency distribution of Rastrelliger faughni (2001-2012)

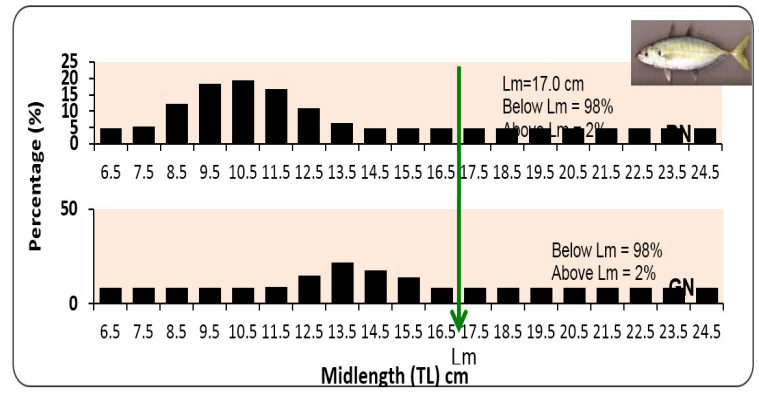

Figure 27. Length Frequency distribution of Atule mate (2001-2012)

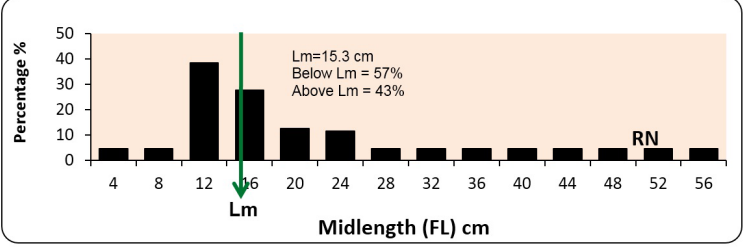

Figure 29. Length Frequency distribution of Auxis rochei (2001-2012)

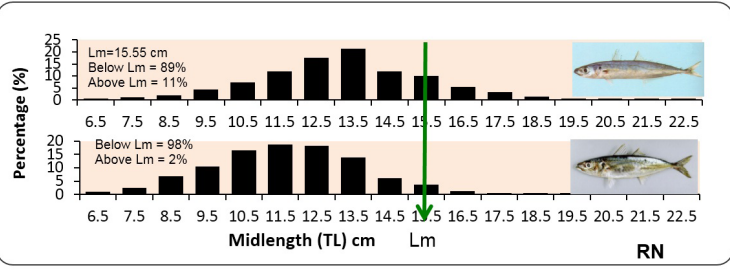

Figure 26. Length Frequency distribution of Decapterus macrosoma and Decapterus russelli (2001-2012)

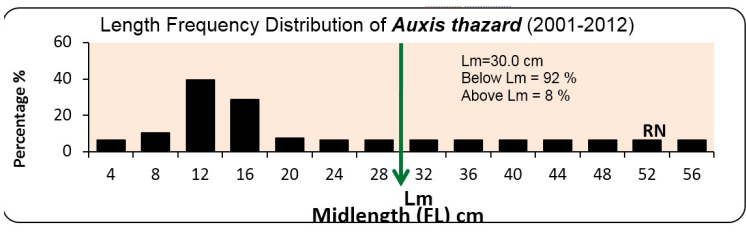

Figure 28. Length Frequency distribution of Auxis thaxard (2001-2012)

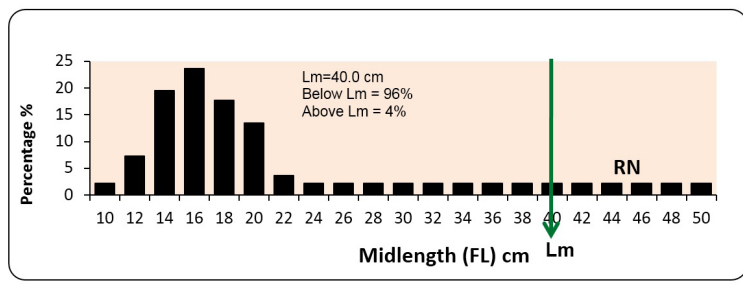

Figure 30. Length Frequency distribution of Euthynnus affinis (2001-2012)

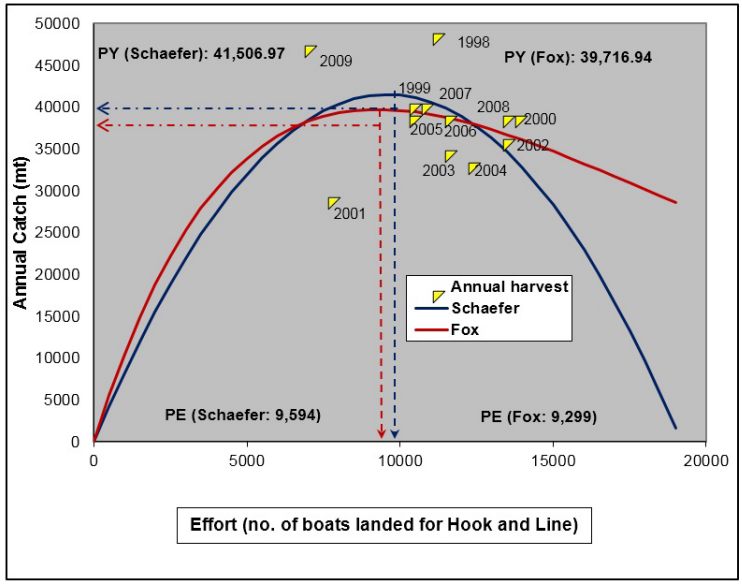

Figure 31. Estimation of Potential Yield (MSY) 